\title{
FITOSSANIDADE
}

\section{WEATHER, CULTIVAR AND DENSITY-DEPENDENT PROCESSES INFLUENCE ON APHID IN ALFALFA $\left(^{\mathbf{1}}\right)$}

\author{
ALEXANDRE DE ALMEIDA E SILVA $\left(2^{*}\right)$; ELENICE MOURO VARANDA $\left({ }^{3}\right)$; \\ JOAQUIM BARTOLOMEU RASSINI $\left({ }^{4}\right)$
}

\begin{abstract}
It is important to understand the effects of weather, insect density and plant cultivar on insect abundance to predict and prevent crop production loss. The present work investigated the influence of such factors on aphid in alfalfa during one year (short term). Data was collected from September/1997 to August/1998 at Canchin Farm (CCPSE-EMBRAPA), São Carlos, State of São Paulo, Brazil. Weather conditions had, in general, little effect on the variation of aphid populations, but Therioaphis maculata abundance was negatively correlated to humidity. Moreover, high maximum temperatures and low levels of rainfall possible favored T. maculata high abundance on Crioula and P3 cultivars. Therefore, appropriate management of this species is required during hot and dry periods. Population variation of Acyrthosiphon spp., T. maculata and Aphis craccivora seems to be regulated by density dependent processes. Resistant cultivar CUF 101 had a lower abundance of $T$. maculata and A. craccivora and a narrower population variation than the other cultivars and may reduce their abundance on field. Long-term studies on population dynamics including the effect of climatic conditions and density-dependent factors on plant quality will contribute to pest management in alfalfa fields.
\end{abstract}

Key words: Herbivory, Hemiptera, Medicago sativa, resistance, population dynamics.

\section{RESUMO}

\section{INFLUÊNCIA DO CLIMA, DA CULTIVAR E DE PROCESSOS DEPENDENTES DA DENSIDADE SOBRE AFÍDEOS EM ALFAFA}

\begin{abstract}
É importante entender os efeitos do clima, da densidade dos insetos e da cultivar sobre a abundância de insetos para se predizer e prevenir perdas na produção das culturas. O objetivo do presente trabalho foi analisar a influência desses fatores sobre afídeos em alfafa no período de um ano. Os dados foram coletados de setembro/ 1997 a agosto/1998 na Fazenda Canchin (CPPSE-EMBRAPA), São Carlos, São Paulo, Brasil. As condições climáticas, em geral, tiveram pequeno efeito sobre a variação populacional dos afídeos, mas a abundância de Therioaphis maculata esteve negativamente correlacionada à umidade. Além disso, as altas temperaturas máximas e os baixos níveis de precipitação pluvial possivelmente favoreceram a alta abundância dessa espécie nas cultivares Crioula e P3. Portanto, torna-se importante o manejo desse afídeo durante períodos quentes e secos. As variações populacionais de Acyrthosiphon spp., T. maculata e Aphis craccivora parecem ser reguladas principalmente por processos dependentes da densidade. Na cultivar resistente CUF 101 observou-se menor abundância de T. maculata e A. craccivora e uma variação populacional menos pronunciada do que nas demais cultivares, podendo ser utilizada para redução da população dessas espécies em campo. Estudos de longa duração, incluindo os efeitos do clima e da densidade sobre a qualidade da planta, vão contribuir para o manejo de afídeos nos alfafais.
\end{abstract}

Palavras-chave: Herbivoria, Hemiptera, Medicago sativa, resistência, dinâmica populacional.

(1) Recebido para publicação em 26 de julho de 2005 e aceito em 13 de fevereiro de 2007.

$\left({ }^{2}\right)$ Laboratório de Entomologia, IPEPATRO, Rua Beira, 7671 (BR 364, km 3,5), 78900-000 Porto Velho (RO), Brasil e Departamento de Biologia-NCT-UNIR, BR 364, km 9,5, 78900-000 Porto Velho(RO). E-mail: alealsil@unir.br (*) Autor correspondente.

$\left({ }^{3}\right)$ Departamento de Biologia, F.F.C.L.R.P, Universidade de São Paulo, Av. dos Bandeirantes, 3900, 14040-901 Ribeirão Preto (SP), Brasil. E-mail:emvarand@ffclrp.usp.br

$\left({ }^{4}\right)$ Embrapa Pecuária Sudeste, Rod. Washington Luiz, km 254, 13560-970 São Carlos (SP), Brasil. E-mail:rassini@cppse.embrapa.br 


\section{INTRODUCTION}

Alfalfa (Medicago sativa) is the most studied livestock feed plant; has a great potential for human nutrition and reduces the ecological costs of agriculture (SMALL, 1996).

The Centro Nacional de Pesquisa de Pecuária do Sudeste (CPPSE-EMBRAPA) has been breeding several alfalfa cultivars in a central region of São Paulo State (São Carlos City) since 1991. The aim is to be investigating basic problems concerning the cultivation of alfalfa under the climatic conditions of the region (RASSINI, 1998). Insect herbivory is one of these problems, and may seriously decrease the forage yield, e.g., the economical loss of 81 million dollars caused by the spotted alfalfa aphid, Therioaphis maculata, from 1954 -56 in the USA (LARA, 1991). CARVALHO et al. (1996) argued that aphids, mainly T. maculata, are possibly the most important alfalfa pests in Brazil. Acyrthosiphon pisum, A. kondoi, T. maculata and Aphis craccivora were the aphid species registered on alfalfa in São Carlos (SousA-Silva et al., 1998)

Abiotic factors, mainly temperature, affect aphid biology (NIELSON and BARNES, 1961; GRAHAN, 1959) but responses may vary depending on the plant cultivar (MORGAN et al., 2001). Aphid population variation on field seems to be affected by both climatic conditions (CARVALHO et al., 1996; BERBERET et al., 1983; Araujo and Sales, 1985) and density-dependent factors, such as crowding (Dixon, 1977).

Studies on the factors influencing insect abundance on short and long term are important to predict and prevent serious production loss due to their large populations. Therefore, this work investigated the effects of weather (temperature, humidity and rainfall), aphid abundance and alfalfa cultivars on the variation and abundance of different aphid species populations on these plants during one year (short term).

\section{MATERIAL AND METHODS}

Alfalfa cultivars Crioula and P3, most cropped in Brazil and the aphid resistant CUF 101 were cultivated at Canchin Farm of EMBRAPA in São Carlos, São Paulo State, Brazil ( $21^{\circ} 10^{\prime} \mathrm{S}$ and $\left.47^{\circ} 53^{\prime} \mathrm{W}\right)$. Plots $(1,5 \times 5 \mathrm{~m})$ were arranged in a randomized block experimental design with three replicates per cultivar . Plants were fertilized $\left(180 \mathrm{~kg} \mathrm{ha}^{-1}\right.$ of $\mathrm{P}_{2} \mathrm{O}_{5}, 150 \mathrm{~kg}$ $\mathrm{ha}^{-1}$ of $\mathrm{K}_{2} \mathrm{O}, 30 \mathrm{~kg} \mathrm{ha}^{-1}$ of FTE BR 12, plus $30 \mathrm{~kg} \mathrm{ha}^{-1}$ of $\mathrm{K}_{2} \mathrm{O}$ after each harvest).

Aphid populations were evaluated once monthly from September/97 to August/98 collecting randomly 100 individual shoots per sample from each alfalfa cultivar on the three plots. Shoots were placed in plastic bags and then stored in freezer $\left(-20^{\circ} \mathrm{C}\right)$. These were later thawed and then shaken for a few seconds in $500 \mathrm{~mL}$ of a soap solution added to the bags. Subsequently, the shoots were removed and the solution was filtered using a fine-mesh cloth. Aphids retained in the filter were transferred to petri dishes, the species T. maculata, A. craccivora and Acyrthosiphon spp. were identified according to the descriptions of SousA-SILVA et al. (1998) and the insects were counted using a stereomicroscope. The two species of Acyrthosiphon found, A. pisum and A. kondoi, were counted together as Acyrthosiphon spp. due to difficulties to sort early instars.

Weather (maximum, minimum and average temperature, humidity and rainfall) data used in this work were provided by the Agroclimatological Station of CPPSE-EMBRAPA and included the period between each sampling, e. g., for the $2^{\text {nd }}$ sampling, weather data from $15 / 09 / 97$ ( $1^{\text {st }}$ sampling) to $10 / 10 /$ 97 ( $2^{\text {nd }}$ sampling).

Nonparametric analyses with two or more factors are not generally acceptable. Therefore ANOVA on Ranks (Kruskal-Wallis) using H critical values distribution for ranks was used to study the variation in the aphid abundance (100 shoots/ sampling/cultivar) among different sampling times and among cultivars. Multiple comparisons among data were performed using the Dunn's test and expressed as aphid abundance (number of individuals) collected. Correlation among variables (climatic and aphid abundance) was estimated using backward stepwise regression (SigmaStat 2.03 - 19921997 SPSS Inc.). Density dependence, i.e. relative growth rate dependence upon population size (Pollard et al., 1987), was detected testing for correlations among dissimilarity (Euclidian distances) matrices of $x_{i}\left(\log _{e} N_{i}\right)$ and $d_{i}\left(x_{i+1}-x_{i}\right)$ of different aphid species on different alfalfa cultivars using Mantel test (NTSYSpc 2.10s, Applied Bioestatistics Inc.); where $\mathrm{N}_{\mathrm{i}}=$ population size ( $\mathrm{i}=1,2,3 \ldots$ samplings) and $\mathrm{d}_{\mathrm{i}}=$ relative growth rate.

\section{RESULTS AND DISCUSSION}

Total aphid abundance on alfalfa varied significantly $(\mathrm{H}=899.3 ; P<0.001)$ among sampling times on the same growth stage of alfalfa (prebloom). On the population dynamics of specific aphid species, Acyrthosiphon spp. had an outbreak in the $9^{\text {th }}$ sampling, but densities remained bellow two individuals per shoot most of the time $(\mathrm{H}=1061.5 ; P$ $<0.0001$ ). The highest abundance of T. maculata was 
in the spring ( $1^{\text {st }}$ to $3^{\text {rd }}$ samplings), but this species had more than two individuals per shoot during several months, except on CUF 101 cultivar $(\mathrm{H}=800.2$; $P<0.0001)$. A. craccivora was present only in a few samples, mainly in the summer, in a very low abundance $(\mathrm{H}=378.7 ; P<0.0001)$ (Figure 1). Growth stage affected the percentage of infected shoots on peas, but was not correlated to A. pisum abundance (McVean et al., 1999). Long population growth duration periods are related to the aphid Metapolophium dirhodum on cereals (HoneK, 1991) maximum abundances, but in the present work, aphids were sampled on very similar time intervals, therefore, maximum abundance of aphids in the present work are not related to population growth duration. Aphid population variation in alfalfa seems to be related to plant quality, e.g., mineral concentration, such as magnesium, sulfur and phosphorus were negatively correlated to total aphid abundance (SILva et al., 2005a) and amino acids, mainly alanine that was positively related to the increase of aphid number on low abundance (up to 4 individuals/shoot) (SiLva et al., 2005b)

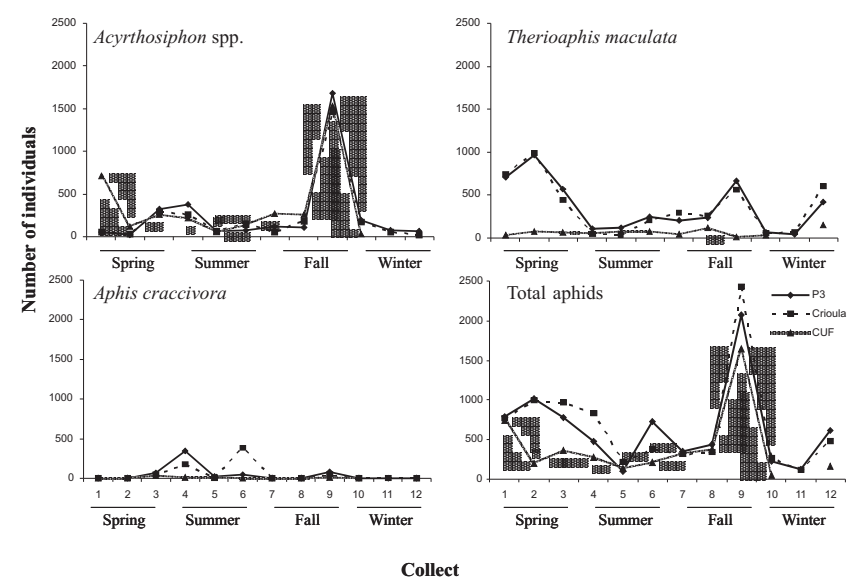

Figure 1. Aphid abundance (number of individuals per 100 shoots) in three cultivars of alfalfa cropped at São Carlos, SP, Brazil. September 15/1997 to August 8/ 1998.

There was a significant lower number of total aphids $(\mathrm{H}=258.3 ; P<0.001)$, T. maculata $(\mathrm{H}=467.4 ; P$ $<0.001)$ and $A$. craccivora $(\mathrm{H}=73.0 ; P<0.001)$ on CUF 101 than on other cultivars, but a higher abundance of Acyrthosiphon spp. $(\mathrm{H}=159.4 ; P<0.001)$ (Figures 1 and 2). Different cultivars (Morgan et al., 2001) affect several biological parameters of aphids, leading to differences in population size. CUF 101 is a multiple resistant cultivar to A. pisum, A. kondoi and T. maculata. However, the occurrence of $A$. pisum (Bournoville et al., 2000) biotypes able to overcome CUF 101 resistance has been already described. Despite that, resistant cultivar affected aphid abundance on alfalfa significantly, mainly for $T$. maculata and A. craccivora and is a possible alternative to reduce their abundance in the field.

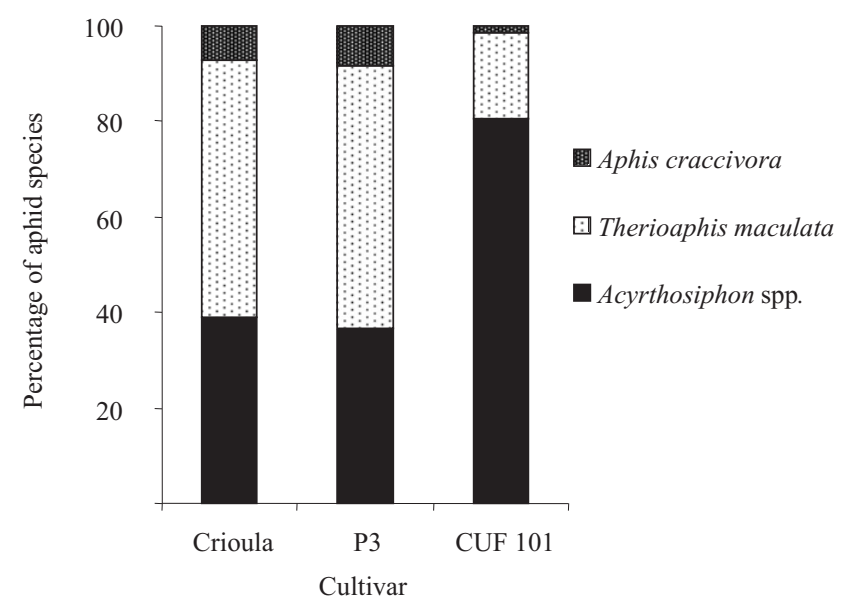

Figure 2. Percentage of aphids species on different alfalfa cultivars cropped at, São Carlos, SP, Brazil. September 15/1997 to August 8/1998.

Interestingly, CUF 101 had the lowest total aphid (Figure 1), but its annual production (ton. of dry matter) was lower than on Crioula or P3 (RAssinI, 1998), suggesting that these two cultivars are tolerant to aphids or that resistance, such as antibiosis on CUF 101, has a metabolic cost, consuming metabolic resources, e.g., carbon and nitrogen compounds, primary used for plant growth (EDWARD and WRATTEN, 1981).

There were just a few significant relationships between aphid number and weather variables. Humidity and minimum temperatures were negatively related to $T$. maculata population abundance on Crioula $\left(\mathrm{r}^{2}\right.$ adj $=0.517 ; \mathrm{F}=6.89$ and $\left.P=0.017\right)$, but only humidity on P3 $\left(\mathrm{r}^{2}{ }_{\text {adj }}=0.502 ; \mathrm{F}=12.4\right.$ and $\left.P=0.006\right)$. Abiotic factors, mainly temperature (SIDDIQUi et al., 1976), also humidity (GRAHAM, 1959) affect alfalfa aphid biology under controlled conditions. However, under field conditions in the present work, it seems that aphid population dynamics is not correlated to most of the climatic factors evaluated. The same was found by other researchers on long-term (JAROSIK and Dixon, 1999; Wool, 2002) and short term (PinheIro et al., 2002) studies of insect population variation. The effect of other variables not evaluated in the present work, such as solar radiation and insolation, may not be neglected because they affected aphid abundance on cotton plants (ARAUjo and SALES, 1985). Moreover, abiotic factors may affect aphid biology differently on different cultivars (MORGAN et al., 2001). 
Table 1. Climatic data (average) of different sampling periods from September 15/1997 to August 8/1998 recorded by

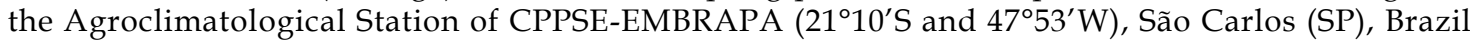

\begin{tabular}{|c|c|c|c|c|c|}
\hline \multirow{2}{*}{ Sampling } & \multicolumn{3}{|c|}{ Mean temperature } & \multirow{2}{*}{ Rainfall } & \multirow{2}{*}{ Humidity } \\
\hline & Maximum & Average & Minimum & & \\
\hline & 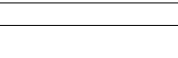 & $-{ }^{\circ} \mathrm{C}-$ & 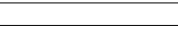 & $\mathrm{mm}$ & $\%$ \\
\hline $1^{\text {st }}(15 / 9 / 97)$ & 29.2 & 21.8 & 13.5 & 23.0 & 54.5 \\
\hline $2^{\text {nd }}(10 / 10 / 97)$ & 28.0 & 20.6 & 10.0 & 46.6 & 70.0 \\
\hline $3^{\text {rd }}(10 / 1197)$ & 31.0 & 23.9 & 18.0 & 199.0 & 84.0 \\
\hline $4^{\text {th }}(08 / 12 / 97)$ & 28.0 & 22.9 & 18.5 & 247.9 & 92.0 \\
\hline $5^{\text {th }}(05 / 1 / 98)$ & 30.0 & 24.4 & 18.5 & 121.8 & 88.0 \\
\hline $6^{\text {th }}(30 / 1 / 98)$ & 30.0 & 24.3 & 19.0 & 160.8 & 86.0 \\
\hline $7^{\text {th }}(02 / 3 / 98)$ & 30.0 & 24.8 & 19.5 & 307.7 & 87.0 \\
\hline $8^{\text {th }}(01 / 4 / 98)$ & 30.0 & 24.0 & 18.7 & 106.2 & 84.0 \\
\hline $9^{\text {th }}(30 / 4 / 98)$ & 27.5 & 22.3 & 17.5 & 105.2 & 80.0 \\
\hline $10^{\text {th }}(01 / 6 / 98)$ & 24.3 & 18.9 & 13.7 & 86.4 & 77.5 \\
\hline $11^{\text {th }}(03 / 7 / 98)$ & 23.4 & 17.5 & 11.7 & 5.0 & 83.0 \\
\hline $12^{\text {th }}(07 / 08 / 98)$ & 25.0 & 18.9 & 11.5 & 23.2 & 69.0 \\
\hline
\end{tabular}

Table 2. Pearson's correlations for aphid species abundance on different alfalfa cultivars

\begin{tabular}{lccc}
\hline Aphid species & $\begin{array}{c}\text { P3 } \\
\text { x Crioula }\end{array}$ & $\begin{array}{c}\text { CUF 101 } \\
\text { x Crioula }\end{array}$ & $\begin{array}{c}\text { CUF 101 } \\
\text { x P3 }\end{array}$ \\
\hline Acyrthosiphon spp. & $0.92^{*}$ & 0.50 & $0.59^{*}$ \\
Therioaphis maculata & $0.90^{*}$ & 0.01 & 0.02 \\
Aphis craccivora & $0.88^{*}$ & 0.13 & 0.01 \\
Total $\left(^{1}\right)$ & $0.92^{*}$ & $0.81^{*}$ & $0.79^{*}$ \\
\hline
\end{tabular}

*Indicate significant correlations $(\mathrm{p}<0.05) .\left({ }^{1}\right)$ total aphid abundance on the specific cultivar. $\mathrm{N}=12$.

Despite that, the negative relation between $T$. maculata population variation and humidity is in agreement to the results of GRAHAM (1959) that related usually lower longevity, fecundity and reproductive periods of this aphid species at high humidity (85$90 \%)$ than at intermediate (65-70\%) and low humidity (25-30\%). Indeed, high abundance of T. maculata was recorded when humidity was close to $73 \%$. NiELson and BARNES (1961) related an increased mortality of this aphid species during high humidity periods by the fungus Entomophthora exitialis. Interestingly, humidity was not correlated to T. maculata population variation on CUF 101, a possible result of the resistant features of this cultivar upon this aphid species affecting population variation differently from the other cultivars (Table 2 )

Prevalence of T. maculata among other aphid species (Figure 2) in the present work might be related to maximum average temperatures (Table 1 ) because high temperatures and also dry weather are suitable to T. maculata (BERBERET et al., 1983). The upper limit of development for this species range from $35-37^{\circ} \mathrm{C}$, the intrinsic rate of increase is highest at $30^{\circ} \mathrm{C}$ and low humidity (25-30\%) (Graham, 1959). Maximum temperature recorded in several sampling periods in the present work were possible deleterious for the other aphid species, because temperatures ranging from $26.4{ }^{\circ} \mathrm{C}$ (Morgan et al., 2001) to $30^{\circ} \mathrm{C}$ (Siddiqui et al., 1976) for $A$. pisum and higher than $25{ }^{\circ} \mathrm{C}$ for $A$. kondoi (BERBERET et al., 1983) exceed the limit for development of these species. Kodet and Nielson (1980) showed that temperatures between $20-25{ }^{\circ} \mathrm{C}$ suppressed the alata production in A. kondoi possibly decreasing its dispersal potential.

Total aphid population variation was correlated among all cultivars and between P3 and Crioula for all aphid species, but not for CUF 101 and other cultivars, except for Acyrthosiphon spp. on P3 (Table 2), suggesting that aphid population dynamics is disrupted by plant cultivar.

Present results indicate that aphid populations on alfalfa were negatively densitydependent (i. e., relative growth rate decreases as population increases) (Figure 3). Despite that, linear models to evaluate density dependence were unreliable with increased data variation and decreased census points (Pollard et al., 1987). Alternatively, Mantel's test was performed to detect density dependence and significant $(P<0.05)$ correlations between growth rate and aphid abundance after data permutation were found for total aphids on all cultivars, also for total Acyrthosiphon spp. and A. craccivora and also for some aphid species on specific cultivars (Table 3 ). 
Table 3. Results (r) of Mantel test for detection of density dependence (population size $X$ growth rate) in aphid populations on different alfalfa cultivars

\begin{tabular}{lcccc}
\hline \multirow{2}{*}{ Aphid species } & \multicolumn{3}{c}{ Cultivars } & \multirow{2}{*}{ Total $\left({ }^{1}\right)$} \\
\cline { 2 - 4 } & P3 & Crioula & CUF 101 & \\
\hline Acyrthosiphon spp. & $0.30^{*}$ & 0.40 & $0.58^{*}$ & $0.47^{*}$ \\
Therioaphis maculata & 0.14 & 0.23 & $0.47^{*}$ & 0.16 \\
Aphis craccivora & $0.47^{*}$ & 0.19 & 0.18 & $0.37^{*}$ \\
Total $\left({ }^{2}\right)$ & $0.50^{*}$ & $0.41^{*}$ & $0.36^{*}$ & - \\
\hline
\end{tabular}

${ }^{*}$ Indicate significant correlation $[\mathrm{p}(\mathrm{Z}$ random $=\mathrm{Z}$ observed $)<0.05]$ for 5000 permutations

${ }^{1}{ }^{1}$ Total aphid abundance of a specific species.

$\left({ }^{2}\right)$ Total aphid abundance of a specific cultivar. $\mathrm{N}=12$.
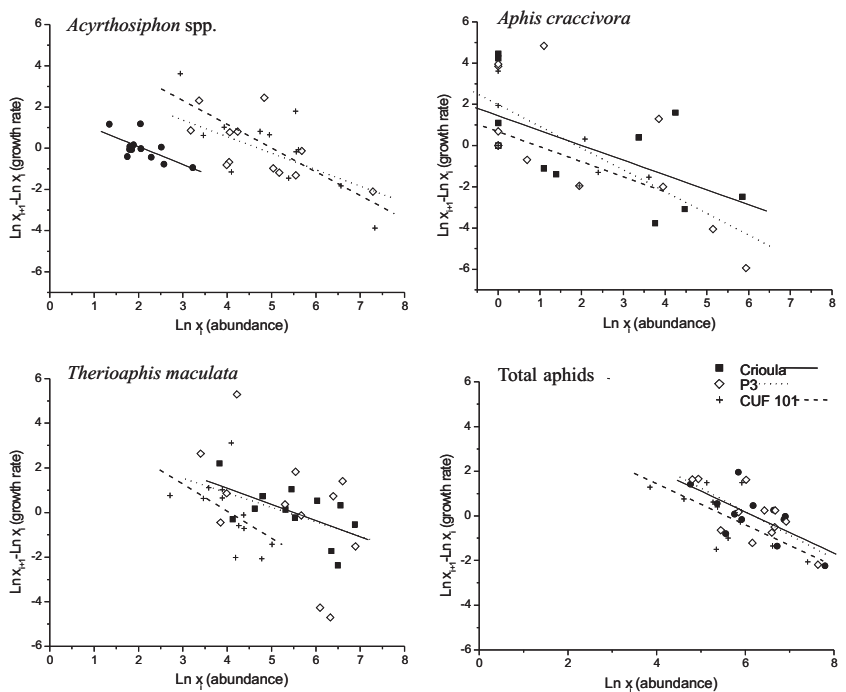

Figure 3. Growth rate vs. population size of different aphid species on alfalfa cultivars cropped at São Carlos, SP, Brazil. September 15/1997 to August 8/1998. Different lines are the linear fitting of scatter plots.

Interactions among different aphid species populations on all alfalfa cultivars suggest that total aphid abundance was regulated by density-dependent mechanisms. Noticeably, density-dependent regulation on CUF 101 occurred at high densities for Acyrthosiphon spp. and low densities for T. maculata and A. craccivora on P3 in a short time scale (i. e., within a year) (Table 3). Sequeira and Dixon (1997) related density dependence in population regulations occurring on different time scales (i. e., within and between years). JAROSIK and DIXON (1999) also related a density-dependent regulation at low densities for the Turkey oak aphid (Mizocallis boerneri). Dixon (1977) argued that qualitative changes in aphids induced by crowding appear to be the most important population regulation factor. McVEAN et al. (1999) related that high densities of $A$. pisum followed by a population crash, similar to the results for Acyrthosiphon spp. in the $9^{\text {th }}$ sampling in this work (Figure 1), resulted from increased alata production suggesting a densitydependent regulation. Summer declines of the Turkey oak aphid (M. boerneri) were also related to migration, increasing linearly with aphid density (KINDLMANN and Dixon, 1996).

It is important to highlight that meteorological factors, similar to density-dependent factors, do not manifest themselves directly but through their effect on plant quality (JAROSIK and Dixon, 1999). Indeed, previous works related correlation among plant quality, i.e., mineral (SILVA et al., 2005a) and amino acids (SILVA et al., 2005b) on alfalfa to aphid variation, but meteorological effects on plant quality were not evaluated. Long-term studies on alfalfa aphid population dynamics including weather conditions and density-dependent factors and their effect on plant quality will certainly contribute to improve pest management programs on alfalfa fields.

\section{ACKNOWLEDGMENTS}

CAPES for financial support and Dr. Rodrigo Santinelo Pereira for his comments on data analysis.

\section{REFERENCES}

ARAÚJO, P. A. C. B.; SALES, F. J. M. Influência do clima e da fenologia do algodoeiro na dinâmica populacional do pulgão. Fitossanidade, Fortaleza, v. 6/9, p. 57-72, 1985.

BERBERET, R. C.; ARNOLD, D. C.; SOTERES, K. M. Geographical occurrence of Acyrthosiphon kondoi Shinji in Oklahoma and its seasonal incidence in relation to Acyrthosiphon pisum (Harris), and Therioaphis maculata (Buckton) (Homoptera: Aphididae). Journal of Economic Entomology, College Park, v. 76, n. 5, p. 1064-1068, 1983.

BOURNOVILLE, R.; SIMON, J.-C.; BADENHAUSSER, I; GIROUSSE, C.; GUILLOUX, T.; ANDRÉ, S. Clones of pea aphid, Acyrthosiphon pisum (Hemiptera: Aphididae) distinguished using genetic markers, differ in their damaging effect on a resistant alfalfa cultivar. Bulletin of Entomological Research, London, v. 90, p. 33-39, 2000.

CARVALHO, A. R.; BUENO, V. H. P.; MENDES, S. Influência de fatores climáticos e do corte na flutuação populacional de pulgões (Homoptera: Aphididae) na cultura da alfafa (Medicago sativa L.), em Lavras, MG. Pesquisa Agropecuária Brasileira, Brasília, v. 31, p. 317-324, 1996.

EDWARD, P. J.; WRATTEN, S. D. Ecologia das interações entre insetos e plantas. São Paulo: EPU, 1981. 71p. 
DIXON, A. F. G. Aphid ecology: life cycles, polymorphism, and population regulation. Annual Review of Ecology and Systematics, Palo Alto, v. 8, p. 329-353, 1977.

GRAHAN, H. M. 1959. Effects of temperature and humidity on the biology of Therioaphis maculata (Buckton). University of California Publications in Entomology, Berkeley, v. 16, n. 2, p.47-80, 1959.

HONEK. A. Factors determining the peak abundance of Metopolophium dirhodum (Homoptera: Aphididae) on cereals. Bulletin of Entomological Research, London, v. 81, p. 57-64, 1991.

JAROSIK, V.; DIXON, A. F. G. Population dynamics of a treedwelling aphid: regulation and density-independent processes. Journal of Animal Ecology, London, v. 68, p. 726$732,1999$.

KINDLMANN, P.; DIXON, A. F. G. Population dynamics of tree-dwelling aphid: individuals to populations. Ecological Modeling, Oxford, v. 89, p. 23-30, 1996.

KODET, R. T. \& NIELSON, M. W. Effect of temperature and photoperiod on the polymorphisms of the blue alfalfa aphid, Acyrthosiphon kondoi. Environmental Entomology, College Park, v. 9, n.1, p. 94-96, 1980.

LARA, F. M. Princípios de resistência de plantas a insetos. São Paulo, Ícone, 1991, 336p.

MCVEAN, R. I. K.; DIXON, A. F. G.; HARRINGTON, R. Causes of regional and yearly variation in pea aphid number in eastern England. Journal of Applied Entomology, Berlin, v. 123, p. 495-502, 1999.

MORGAN, D.; WALTERS, K. F. A.; AEGERTER, J. N. Effect of temperature and cultivar on the pea aphid, Acyrthosiphon pisum (Homoptera: Aphididae) life history. Bulletin of Entomological Research, London, v. 91, p. 47-52, 2001.

NIELSON, M. W.; BARNES, O. L. Populations of the spotted alfalfa aphid in Arizona in relation to temperature and rainfall. Annals of the Entomological Society of America, Columbus, v. 54, p. $441-448,1961$.
PINHEIRO, F.; DINIZ, I R.; COELHO, D.; BANDEIRA, P. S. Seasonal pattern of insect abundance in the Brazilian cerrado. Austral Ecology, Canberra, v. 27, p. 132-136, 2002.

POLLARD, E.; LAKHANI, K. H.; ROTHERY, P. The detection of density-dependence from a series of annual censures. Ecology, Washington, v.68, n. 6, p. 2046-2055, 1987.

RASSINI, J. B. Alfafa (Medicago sativa L.): estabelecimento e cultivo no Estado de São Paulo. São Carlos: EMBRAPA-CPPSE, 1998. 27p.

SEQUEIRA, R. ; DIXON, A. F. G.. Population dynamics of treedwelling aphids: the importance of seasonality and time scale. Ecology, Washington, v.78, n. 8, p. 2603-2610, 1997.

SIDDIQUI, V. W.; BARLOW, C. A. ; RANDOLPH, P. A Effects of some constant and alternating temperatures on the population growth of the pea aphid Acyrthosiphon pisum (Homoptera: Aphididae). Canadian Entomologist, Ottawa, v. 105, n. 1, p. 145-156, 1976.

SILVA, A. A. E.; VARANDA, E. M. ; PRIMAVESI, A. C. Effect of the inherent variation in mineral concentration of alfalfa cultivars on aphid populations. Bragantia, Campinas, v. 64, n. 2, 233-239, 2005a.

SILVA, A. A. E.; VARANDA, E. M. Relationship between amino acid concentration and aphid (Hemiptera: Aphididae) abundance on alfalfa (Medicago sativa L.). Acta Biologica Leopoldensia, São Leopoldo, v. 27, n. 1, p. 33-42, 2005b.

SMALL, E. Adaptations to herbivory in alfalfa (Medicago sativa). Canadian Journal of Botany, Ottawa, v.74, p. 807-822, 1996.

SOUSA-SILVA, C. R.; PACHECO, J. M.; RASSINI, J. B.; ILHARCO, F.A. Afídeos da alfafa no Brasil (Homoptera, Aphidoidea). Revista Brasileira de Entomologia, Curitiba, v. 41, n. 2-4, p. 285-288, 1998.

WOOL, D. Herbivore abundance is independent of weather? A 20 year study of a galling aphid Baizongia pistaciae (Homoptera: Aphidoidea). Population Ecology, Tokyo, v. 44: 281-291, 2002. 